Published in Journal of Hospitality \& Tourism Education, 2018, vol. 30, no. 2, pp. 71-84 which should be cited to refer to this work

DOI: https://doi.org/10.1080/10963758.2018.1436969

\title{
Investigating the impact of relationship quality during internship on Millennials' career decisions and gender differences
}

\author{
Cindy Yoonjoung Heo, PhD. \\ Assistant Professor \\ École hôtelière de Lausanne \\ HES-SO / University of Applied Sciences Western Switzerland \\ Route de Cojonnex 18 \\ 1000 Lausanne \\ Email: cindy.heo@ehl.ch \\ Seongseop (Sam) Kim \\ Associate Professor \\ School of Hospitality and Tourism Management \\ The Hong Kong Polytechnic University \\ Hong Kong, China \\ Email: sam.kim@polyu.edu.hk
}

\author{
Bona Kim \\ Assistant Professor \\ Business Administration and Tourism and Hospitality Management \\ Mount Saint Vincent University \\ Halifax, NS, Canada \\ Email: Bona.kim2@msvu.ca
}

Corresponding Author: Cindy Yoonjoung Heo 


\begin{abstract}
The hospitality industry has been struggling to attract and retain quality employees. Labor force demographics in the hospitality industry are changing. The first wave of Millennials started to enter the workforce and Millennials are the fastest growing segment. In addition, the female rate of participation in today's hospitality workforce is growing. Even though several researchers have studied Millennials as hospitality employees, limited research has explored the importance of the quality of relationships Millennials have with colleagues and customers; in addition, gender differences among Millennials have not extensively been examined. The Commitment-Trust (CT) theory suggests that relationship commitment and trust encourage cooperative behaviors that sustain long-term relationships. This study attempted to investigate whether relationship quality encountered by Millennials during their internships has an impact on their job satisfaction, career decisions based on CT theory; in addition, gender differences in relationship quality are examined.
\end{abstract}

\title{
Keywords
}

Millennials, Generation Y, Relationship Quality, Commitment-Trust (CT) Theory, Gender Difference 


\section{Introduction}

The global hospitality industry has been struggling to attract and retain quality employees and the shortage of skillful and knowledgeable employees is a critical issue (Ferris, Berkson, \& Harris, 2002; Freeland, 2000). The scarcity is being felt not only at the managerial levels but also in terms of finding frontline employees, whether graduates or students (Siu et al., 2012). Labor force demographics in the hospitality industry are changing. The first wave of the Millennial generation has begun to enter the workforce and the Millennial generation is the fastest growing segment of today’s workforce. The Millennial generation, also called Generation Y, Gen Yers, Gen Y, Nexters, Generation www, Echo Boomers, and the Internet Generation, typically refers to the generation of people born between the early 1980s and the early 2000s, although there is no consensus over the exact dates of birth that define Millennials. According to population estimates released by the U.S. Census Bureau in 2015, Millennials have surpassed Baby Boomers as the largest living generation in the U.S. Because the millennial generation is now the largest cohort to emerge since the baby boom generation - and will grow significantly as a proportion of the workforce over the next 20 years - employers may need to understand who they are and how they behave. The characteristics of Millennial employees are often regarded as problematic by some employers (Cairncross \& Buultjens, 2007). Even though many researchers have studied Millennials as hospitality employees, limited research has explored the importance of their relationship quality with fellow colleagues and customers in the workplace.

Previous studies found that students' experience in the hospitality industry has a negative impact on their perceptions and attitudes towards careers in the sector (Barron \& Maxwell, 1993; Johns \& McKechnie, 1995; Jenkins, 2001). Fox (2001) revealed that a poor internship experience was the biggest reason why young people leave the industry quickly. Brown et al. (2015) found that long hours and compensation are the main reasons why young people quickly leave the industry. 
Therefore, the purpose of this study is to examine how relationship quality with colleagues and customers during internship, during Millennials’ internships, is related to their job satisfaction and commitment to the hospitality industry upon graduation. This study also aimed to identify the role of trust and commitment as antecedents of relationship quality and the moderating effect of gender on relationship quality. Today's hospitality industry has greatly changed in terms of the gender structure of its workforce (Petrović et al., 2014). As the number of women employed in the hospitality industry has increased at all levels (Pinar et al., 2011; Santero-Sanchez et al. 2015), hotel managers need to consider gender differences when implementing HR strategies. Therefore, this study examined the gender differences in the relationship between relationship quality, job satisfaction and career intention.

\section{Literature Review}

\subsection{Millennials}

A generation is defined as “an identifiable cluster that shares birth years, age, location and important life events at critical developmental stages, divided by 5 to 7 years in the first wave, core group and last wave” (Kupperschmidt, 2000, p. 66). Each generation experiences similar social or historical events that shape their perspectives, which affect the approach they use to interpret the world. These interpretations have a relatively stable effect on their lives (Westerman \& Yamamura, 2006). The shared experiences will have an influence on how a cohort member feels towards authority and organizations, what their work-related values are, and how a person would act to satisfy their values and desires (Kupperschmidt, 2000).

Millennials have benefited from rapidly advancing technological changes such as access to both computers and the Internet (Erickson, 2008). Martin (2005) listed a number of qualities that define Millennials: they are technologically knowledgeable, independent, self-reliant and entrepreneurial. Furthermore, this group of young people prefers to complete tasks in their own 
way and at their own pace. Millennials engage in multitasking and can be very selective in the way they receive information (Solnet \& Hood, 2008). Millennial employees are often described as more demanding than previous generations and not afraid of expressing their opinions (Knight, 2000) and prefer being treated as partners in organizations (Earle, 2003). With a low tolerance for boredom, Millennial employees enjoy new challenges and expect to be shown respect and given responsibility from early on in their career (Glass, 2007; Martin, 2005).

The recruitment and retention of Millennial employees has become a major concern for the hospitality industry. Today's business environment has become very competitive, maintaining skilled employees is the major differentiating factor for most organizations. Replacing existing employees is costly to companies and destructive to service delivery (Samuel \& Chipunza, 2009). High turnover can be damaging to the organization's productivity. It is therefore imperative for hotels to reduce, to the strict minimum, the frequency at which employees, particularly those who are crucial to its operations, leave. Millennials will account for roughly $50 \%$ of the US workforce in 2020 and 75\% of the global workforce by 2030 (Meister, 2012). It is thus critical to understand what factors influence Millennials' career intentions. Otherwise, the industry will face difficulties in recruiting and retaining quality employees and subsequently suffer from labor loss. Different studies in different regions vary regarding the intention to stay in the hospitality industry. A study in Australia (Richardson, 2008) has found that over $90 \%$ of the respondents did not intend to work in the industry. In addition, a comparative study between Australia and Hong Kong on graduates illustrated that about $50 \%$ of the hospitality graduates sampled did not work in a hospitality related field at the time of the study (King et al., 2003). Similar results were reported in Europe where less than $50 \%$ of students said they would definitely choose the hospitality industry as their career choice (Jenkins, 2001). In conclusion, young students in the hospitality field do not have a strong 
career intention towards the industry. It is important to understand the underlying factors regarding hospitality students’ career intentions in order to retain young talent in the industry.

\subsection{Internship experience and career intentions}

Understanding students' career intentions is an important issue in retaining quality employees for the hospitality industry (Chuang et al. 2007; Chuang \& Dellmann-Jenkins, 2010). Realizing the importance of career intentions, academia in the hospitality field actively studies this topic. Many studies pointed out the problem that hospitality graduates do not wish to continue their career in the industry after graduation (Barron \& Maxwell, 1993; Lam \& Ching, 2007; Leslie \& Richardson, 2000; Raybould \& Wilkins, 2005; Richardson, 2008; Seyitog־ lu \& Yirik, 2015). A longitudinal study in Scotland (Getz, 1994) found that the attitudes towards a potential career in the hospitality industry had decreased significantly over a period of 14 years and the major reason was that jobs in the industry were not perceived as desirable. Pavesic and Brymer (1990) revealed that many hospitality graduates left the industry immediately upon graduation, and then looked for jobs in other areas besides hotels or related services. Barron and Maxwell (1993) found that students just beginning their tourism and hospitality studies have views of the industry that stand in stark contrast with those held by students who already have work experience in the hospitality industry. A similar study (Kelley-Patterson \& George, 2001) found that the industry was perceived as low paying with long hours and that such perceptions, consequently, led students to not intend to stay in the hospitality industry; moreover, Jenkins (2001) also shared a similar finding, that once students experienced working conditions in the industry, a negative perception was generated and resulted in lower level of commitment for employment in the hospitality industry. As students working in the industry during the internship program, the content of their daily work has a direct impact on students’ perception of their work and subsequently influences their perception of the industry. 
The hospitality industry expects entry-level employees to have a solid and practical understanding of the industry including knowledge and skills developed through industry-based experiences (Alonso \& O’Neill, 2011; Blake \& Worsdale, 2009; Millar, Mao, \& Moreo, 2011; Raybould \& Wilkins, 2005; Tesone, 2002) such as off-campus internships. Therefore, most academic programs in hospitality require students to participate in internships, which is a structured and career-related work experience prior to graduation. Entry-level positions are arranged for internship participants under the supervision of mentors and trainers (Feldman, 2003). Internships are an opportunity to close the gap between theory and practice and are an integral part of a student's career development and may have numerous positive impacts on students (Lam \& Ching, 2007). Besides serving as an essential component of the university education, an internship can also help in developing students' network in the industry while being compensated for their work (Seymore II \& Higham, 1996), thus becoming more competitive in the labor market (Neuman, 1999).

However, several scholars have discussed the negative influence of an internship experience on a young person's career decisions. Fox (2001) pointed out that poor internship experiences are a major reason why young people leave the hospitality industry. According to Richardson's (2010) study, although the majority of Generation Y students stated the hospitality industry was interesting (85.5\%) and they would be able to learn new things (75.1\%), half of the respondents had already planned to leave the industry citing stress as the major reason, and 58.3\% of those students were considering careers outside the hospitality industry. Problems related to internships include low salary and no pay for overtime duties (McMahon \& Quinn, 1995). Pavesic and Brymer (1990) pointed out that long working hours can cause burnout even in career-oriented people (Pavesic \& Brymer, 1990). Some companies are not aware of what to expect from interns, how to train them and what skill levels they should obtain during their internship period (Huyton, 
1991). Some employers may not fully understand the objectives of the internship or may treat interns as cheap labor (Lam \& Ching, 2007). Because some internships are taken for credit, students have to pay tuition and fees to participate and students normally receive a significantly lower wage than regular employees would earn. Furthermore, the company is under no obligation to offer a student employment at the end of the internship or upon graduation.

Although previous research on hospitality students’ career intentions (e.g., Chuang \& Dellmann-Jenkins, 2010; Getz, 1994; Richardson, 2008) has mainly focused on identifying the factors which influence students' career intentions, these studies have failed to evaluate the relationship among the factors. For example, Tse (2010) analyzed the content of 279 student internship reports and found that working relationships with colleagues rank, by far, as the most important component of the internship experience. However, his study did not examine how relationships with colleagues and customers are related to commitment to the hospitality industry upon graduation. It is important to identify the underlying relationships in order to better influence students' career intentions both from the perspective of the academic institution and the industry.

\subsection{Relationship quality}

The literature on relationship quality suggests that relationship quality between the parties involved is a key determinant of loyalty (Walter et al., 2003). Relationship quality is defined as the overall depth and climate of interpersonal connection, association or involvement (Johnson, 1999) and determines how well the whole relationship fulfils expectations, predictions, goals and desires (Jarvelin \& Lehtinen, 1996). The Commitment-Trust (CT) theory proposes that commitment and trust are key variables for successful relationships because they promote cooperative behaviors and encourage participants to maintain long-term relationships (Morgan \& Hunt, 1994). Trust is viewed as a belief, sentiment or expectation about an exchange partner's trustworthiness that results from the partner’s expertise, reliability or intentionality (Blau, 1964; Pruitt, 1981) and 
commitment refers to the desire to maintain valuable, ongoing relationships (Moorman et al., 1992).

CT theory has been applied not only in marketing literature regarding relationships but also in various other fields. For example, Becerra and Gupta (1999) attributed negative outcomes to a lack of trust and positive results to high-trust relationships and showed that overall performance is enhanced when trust problems are minimized. Kwon and Suh (2004) later confirmed a positive relationship between the level of commitment and the degree of trust in a supply chain context and also showed that information sharing improves trust levels. Furthermore, Park et al. (2005) investigated the relationships between teamwork behaviors in schools and teacher-team commitment and assessed the impact of teachers' demographic characteristics and trust. Their study found that better teamwork is significantly associated with teacher-team commitment and trust appears to be an important factor in this relationship. Adidam et al. (2004) investigated the effect of key variables on students' retention in the context of a business school and their results indicated that trust and commitment are the key elements in developing long-term relationships.

Moreover, abundant research in human resource management (HRM) literature has shown the importance of human relations in the workplace. Maintaining a strong employer-employee relationship can be the key to the ultimate success of a company. The hospitality literature has also stressed the importance of the relationship between service provider and customers. For example, Mattila (2001) applied CT theory to test the relationship between customers' emotional bonding and loyalty to the restaurant. Similarly, Sui and Baloglu (2003) examined the antecedents and consequences of commitment to hotel casinos targeting local customers and found the most influential variables on behavioral outcomes of loyalty are trust and emotional attachment. While most previous studies regarding CT theory and the HRM literature have focused on relationship quality between two parties (e.g., customer and service provider in CT theory; employee and 
employer in HRM), this study included relationship quality among three parties (i.e., Millennial interns, customers and colleagues) in order to identify the relative importance of relationships with customers and colleagues in determining job satisfaction and career intentions. According to CT theory, this study hypothesized that the level of commitment is positively related to the level of trust, and commitment and trust were included as two key variables for relationship quality in the conceptual model (Figure 1).

\subsection{Gender differences}

Previous research showed that individual differences would affect the relationship between the service provider and the customer. In particular, the role of gender in management has long been a subject in academia. Gender difference is found in interpersonal behavior and interpersonal relationships, which suggest that men and women differ in the way they participate in social relationships (Eagly, 1987; Reevy \& Maslach, 2001). Studies have investigated the moderating role of gender in a number of organizational contexts including perceptions of job satisfaction and promotion (Witt \& Nye, 1992), trust in supervisors (Lee \& Farh, 1999) and leadership (Cole, 2004). Witt and Nye (1992) argued that women tend to strive for interpersonal or social success while men tend to seek exploitative or competitive success in their interaction goals. However, in Lee and Farh’s study (1999), gender did not moderate any other justice-outcome relationships.

Then, the next question is whether the influences of relationship quality during Millennials’ internships on job satisfaction and career intention are equal for both males and females. If any gender differences are found, they will have important implications for hospitality businesses. In

the last 10 years, the profile of students and their subsequent performance has altered considerably in favor of women. Schoffstall (2015) compared 136 hospitality programs throughout the United States and reported the current gender breakdown of undergraduate students (66.7\% female). However, after entering the hospitality industry, female graduates are more likely to leave the 
industry than their male counterparts (Whitelaw \& Gillet, 2003). Therefore, the issue of how to recruit, train, empower and retain female employees in the hospitality industry has emerged as a critical issue.

Previous studies in relationship research found that men and women differ in the way in which they create and sustain intimate relationships (Monga, 2002). Women possess a socializingoriented communal behavior while men demonstrate task-oriented behavior (Eagly, 1987). Caruso et al. (2002) pointed out that female employees have a tremendous ability to understand other people's emotions and are in closer communication with others. Noble et al. (2006) found that women became loyal to a local merchant with social interaction motives, whereas men's loyalty to the same firm is driven more by information acquisition motives. Sánchez -Franco et al. (2009) discovered that the influence of trust on commitment and of commitment on loyalty was significantly stronger for females than males in the context of an internet service provider. Similarly, in Ndubisi’s study (2006), significant gender differences exist in the trust-loyalty relationship in the context of bank services. Female customers tend to be more loyal than male customers when the bank is highly trustworthy, but gender does not moderate the relationship between commitment, communication, conflict handing, and loyalty (Ndubisi, 2006). On the other hand, Melnyk et al. (2009) argued that female consumers are always more loyal than male consumers. Compared to male customers, female customers tend to be more loyal to individual people or organizations, such as an individual service provider; this tendency is reversed when the target of loyalty is a group of people, such as a company (Melnyk et al., 2009).

As the number of women employed in the hospitality industry increases, several studies in the hospitality field have explored gender difference issues from an organizational behavior perspective. For example, Ng and Pine (2003) reported that female executives in the hotel industry tend to downplay the difficulties, and to favor personal, against institutional, strategies to 
overcome difficulties. The study published by Kim et al. (2009) found that the effect of role stress on job satisfaction is significantly stronger for female employees than male employees. Kara et al. (2012) explored gender differences on job satisfaction and study results indicated that significant gender differences exist with regard to the "using ability in the job dimension" of job satisfaction. In conclusion, previous studies assert that gender does exert an influence on the way in which individuals engage in relationships. It is apparent that there should also be differences between men and women with regard to their relationships with customers and colleagues. Therefore, gender has been included in this study as a moderator in the relationships between relationship quality during internship, job satisfaction and career decisions.

\section{Methodology}

The conceptual model of this study is based on the Commitment-Trust (CT) theory proposed by Morgan and Hunt (1994). The measures for the constructs were adapted from Morgan and Hunt (1994), Crosby et al. (1990), Moorman et al. (1992) and Wong and Sohal (2002). For each construct, multiple-item measurement models rather than single-item indicators were used to avoid item response bias (Frazier et al., 1989). The questionnaire employed a seven-point scale ranging from strongly disagree to strongly agree for each question. A convenience sample of undergraduate students in Hong Kong was used to test the proposed model. The data was collected using paper-based questionnaires from undergraduate students of one university in Hong Kong who had completed their internships within the last three months.

\section{Results}

\subsection{Respondents' profiles}

Table 1 presents the demographic profiles of Millennials who participated in the present study. A total of 494 questionnaires were collected but 23 questionnaires were discarded because of missing data. Of the 471 respondents, 53.5\% $(n=252)$ were female and $46.5 \%(n=219)$ were male. 
The range of ages was distributed from 19 to 26 years old. 58\% of respondents were between 21 and 22 years old. About 69\% of them indicated the length of internship period as between one and six months

\section{Table 1. Respondents’ profile}

\begin{tabular}{|c|c|c|c|}
\hline \multicolumn{2}{|r|}{ Characteristics } & Frequency & Percentage (\%) \\
\hline \multirow{2}{*}{ Gender } & Male & 219 & 46.5 \\
\hline & Female & 252 & 53.5 \\
\hline \multirow{8}{*}{ Age } & 19 & 16 & 3.4 \\
\hline & 20 & 66 & 14.0 \\
\hline & 21 & 121 & 25.7 \\
\hline & 22 & 152 & 32.3 \\
\hline & 23 & 88 & 18.7 \\
\hline & 24 & 21 & 4.5 \\
\hline & 25 & 6 & 1.3 \\
\hline & 26 & 1 & 0.2 \\
\hline \multirow{5}{*}{ Program } & BSc in Hotel Management & 257 & 54.6 \\
\hline & BSc in Tourism Management & 142 & 30.1 \\
\hline & BSc in Convention and Event Management & 46 & 9.8 \\
\hline & HD in Hotel Management & 24 & 5.1 \\
\hline & HD in Tourism Management & 2 & 0.4 \\
\hline \multirow{5}{*}{$\begin{array}{l}\text { Length of } \\
\text { internship } \\
\text { period } \\
\text { (month) }\end{array}$} & 1-3 months & 201 & 42.6 \\
\hline & 4-6 months & 126 & 26.7 \\
\hline & 7-9 months & 14 & 3.0 \\
\hline & 10-12 months & 115 & 24.3 \\
\hline & More than 13 months & 15 & 3.1 \\
\hline \multirow{4}{*}{ Internship offer } & School assigned & 71 & 15.1 \\
\hline & Student found the internship & 140 & 29.7 \\
\hline & Student found the internship through the school & 241 & 51.2 \\
\hline & Other & 19 & 4.0 \\
\hline \multirow{2}{*}{ First time } & Yes & 331 & 70.3 \\
\hline & No & 140 & 29.7 \\
\hline & Total & 471 & 100 \\
\hline
\end{tabular}

\subsection{Measurement model analysis}

To ensure the validity of the measurement model, an exploratory factor analysis (EFA) was carried out. Although all measurement items were validated from previous research papers, we conduct the EFA and CFA, because the study context was different from that of previous studies. Two groups were randomly divided by using SPSS. 234 samples were used for EFA, whereas 237 samples were used for CFA. Table 2 illustrates the results of exploratory factor analysis and 
reliability tests. Only variables with a factor loading of greater than 0.5 were chosen, in accordance with Hair et al. (1998). Four items with a factor loading of less than 0.5 have been deleted (i.e., CT3, CT4, ET4 \& IL1). The results of exploratory factor analyses using varimax rotation and reliability tests were reported in Table 2 . All the factor loadings that measure correlations between the observed measurements and the factors for seven constructs were between 0.880 and 0.987 , which meets the criterion of an acceptable factor loading (Hair et al., 2008). The constructs were considered to maintain the internal consistency of measurements.

Table 2 Results of exploratory factor analysis and reliability tests $(N=234)$

\begin{tabular}{|c|c|c|c|c|c|c|c|}
\hline Construct & Items & Factor loading & Mean & $\begin{array}{c}\text { Std. } \\
\text { Deviation }\end{array}$ & $\begin{array}{l}\text { Eigen } \\
\text { value }\end{array}$ & Variance (\%) & $\begin{array}{l}\text { Reliability } \\
\text { alpha }\end{array}$ \\
\hline \multirow{2}{*}{$\begin{array}{c}\text { Customer } \\
\text { trust }\end{array}$} & CT1 & .898 & 4.427 & 1.063 & \multirow{2}{*}{1.611} & \multirow{2}{*}{80.552} & \multirow{2}{*}{.757} \\
\hline & CT2 & .898 & 4.504 & 1.147 & & & \\
\hline \multirow{3}{*}{$\begin{array}{c}\text { Customer } \\
\text { commitment }\end{array}$} & CC1 & .936 & 5.420 & 1.118 & \multirow{3}{*}{2.562} & \multirow{3}{*}{85.397} & \multirow{3}{*}{.914} \\
\hline & CC2 & .924 & 5.340 & 1.125 & & & \\
\hline & CC3 & .913 & 5.240 & 1.177 & & & \\
\hline \multirow{4}{*}{$\begin{array}{l}\text { Relationship } \\
\text { quality with } \\
\text { customers }\end{array}$} & CRQ1 & .976 & 3.936 & 1.581 & \multirow{4}{*}{3.755} & \multirow{4}{*}{93.880} & \multirow{4}{*}{.978} \\
\hline & CRQ2 & .968 & 3.949 & 1.434 & & & \\
\hline & CRQ3 & .967 & 3.919 & 1.569 & & & \\
\hline & CRQ4 & .965 & 3.927 & 1.525 & & & \\
\hline \multirow{3}{*}{$\begin{array}{l}\text { Employee } \\
\text { trust }\end{array}$} & ET1 & .965 & 5.040 & 1.261 & \multirow{3}{*}{2.711} & \multirow{3}{*}{90.362} & \multirow{3}{*}{.947} \\
\hline & ET2 & .955 & 5.200 & 1.232 & & & \\
\hline & ET3 & .931 & 4.980 & 1.218 & & & \\
\hline \multirow{3}{*}{$\begin{array}{c}\text { Employee } \\
\text { commitment }\end{array}$} & EC1 & .952 & 5.444 & 1.080 & \multirow{3}{*}{2.550} & \multirow{3}{*}{85.007} & \multirow{3}{*}{.911} \\
\hline & EC2 & .932 & 5.645 & 1.126 & & & \\
\hline & EC3 & .880 & 5.679 & 1.074 & & & \\
\hline \multirow{4}{*}{$\begin{array}{c}\text { Relationship } \\
\text { quality with } \\
\text { employees }\end{array}$} & ERQ1 & .982 & 4.010 & 1.781 & \multirow{4}{*}{3.820} & \multirow{4}{*}{95.508} & \multirow{4}{*}{.984} \\
\hline & ERQ2 & .977 & 3.930 & 1.721 & & & \\
\hline & ERQ3 & .976 & 3.930 & 1.774 & & & \\
\hline & ERQ4 & .974 & 3.960 & 1.751 & & & \\
\hline \multirow{2}{*}{$\begin{array}{c}\text { Job } \\
\text { satisfaction }\end{array}$} & JS1 & .946 & 5.260 & 1.259 & \multirow{2}{*}{1.788} & \multirow{2}{*}{89.412} & \multirow{2}{*}{.876} \\
\hline & JS2 & .946 & 5.050 & 1.471 & & & \\
\hline $\begin{array}{l}\text { Intention to } \\
\text { leave }\end{array}$ & IL & - & 3.992 & 1.662 & - & - & - \\
\hline \multicolumn{8}{|c|}{$\begin{array}{l}\text { * Note: 1. CT (customer trust), CC (customer commitment), ET (employee trust), EC (employee commitment), JS } \\
\text { (job satisfaction), and IL (intention to leave) were measured on a seven-Likert scale with } 1 \text { indicating "Strongly } \\
\text { disagree”, } 4 \text { indicating "Neutral”, to } 7 \text { indicating "Strongly agree” } \\
\text { 2. CRQ (relationship quality with customers) and ERQ (relationship quality with employees) were measured on a } \\
\text { seven semantic differential scales anchored by with } 1 \text { indicating "Positive scales” to } 7 \text { indicating "Negative scales” }\end{array}$} \\
\hline
\end{tabular}


Before conducting the SEM analyses, a confirmatory factor analysis (CFA) was performed to confirm the proposed measurement model (Kline, 1998), and results are presented in Table 3. $(\mathrm{TLI}=0.968, \mathrm{NFI}=0.945, \mathrm{CFI}=0.975, \mathrm{GFI}=0.891, \mathrm{AGFI}=0.848$, and RMSEA=0.057). In general, these indicated an acceptable fit between the model and the data. Reliability alphas were also estimated in order to assess composite construct reliability (CCR) and results indicate that the internal consistency of the items is satisfactory (Fornell \& Larcker, 1981; Hair et al., 2009; Nunnally, 1978). The Average Variance Extracted (AVE) for all constructs was greater than the corresponding squared standardized correlation, establishing the discriminant validity of the factors (Fornell \&Larcker,1981).

Table 3 Results of confirmatory factor analysis of overall student dataset $(N=237)$

\begin{tabular}{|c|c|c|c|c|c|c|c|c|}
\hline Construct & Items & $\begin{array}{l}\text { Factor } \\
\text { loading }\end{array}$ & SMC & Estimate & $\mathrm{SE}$ & t-value & $\mathrm{AVE}^{1}$ & $\mathrm{CCR}^{2}$ \\
\hline \multirow{2}{*}{$\begin{array}{c}\text { Customer } \\
\text { trust }\end{array}$} & CT1 & .959 & .920 & 1.231 & .161 & 7.648 & \multirow{2}{*}{0.749} & \multirow{2}{*}{0.855} \\
\hline & CT2 & .747 & .558 & - & & & & \\
\hline \multirow{3}{*}{$\begin{array}{c}\text { Customer } \\
\text { commitment }\end{array}$} & CC1 & .811 & .658 & .985 & .071 & 13.946 & \multirow{3}{*}{0.670} & \multirow{3}{*}{0.858} \\
\hline & CC2 & .941 & .886 & 1.147 & .074 & 15.508 & & \\
\hline & CC3 & .801 & .642 & - & & & & \\
\hline \multirow{4}{*}{$\begin{array}{l}\text { Relationship } \\
\text { quality with } \\
\text { customers }\end{array}$} & CRQ1 & .924 & .853 & .976 & .033 & 29.962 & \multirow{4}{*}{0.800} & \multirow{4}{*}{0.941} \\
\hline & CRQ2 & .921 & .848 & .878 & .030 & 29.581 & & \\
\hline & CRQ3 & .969 & .938 & 1.011 & .026 & 38.782 & & \\
\hline & CRQ4 & .962 & .926 & - & & & & \\
\hline \multirow{3}{*}{$\begin{array}{l}\text { Employee } \\
\text { trust }\end{array}$} & ET1 & .909 & .827 & 1.206 & .082 & 14.720 & \multirow{3}{*}{0.736} & \multirow{3}{*}{0.892} \\
\hline & ET2 & .951 & .905 & 1.235 & .082 & 15.108 & & \\
\hline & ET3 & .748 & .560 & - & & & & \\
\hline \multirow{3}{*}{$\begin{array}{c}\text { Employee } \\
\text { commitment }\end{array}$} & EC1 & .827 & .684 & .963 & .063 & 15.358 & \multirow{3}{*}{0.719} & \multirow{3}{*}{0.885} \\
\hline & EC2 & .880 & .774 & 1.004 & .060 & 16.626 & & \\
\hline & EC3 & .860 & .740 & - & & & & \\
\hline \multirow{4}{*}{$\begin{array}{l}\text { Relationship } \\
\text { quality with } \\
\text { employees }\end{array}$} & ERQ1 & .974 & .948 & .987 & .019 & 51.120 & \multirow{4}{*}{0.876} & \multirow{4}{*}{0.966} \\
\hline & ERQ2 & .968 & .937 & .919 & .019 & 47.931 & & \\
\hline & ERQ3 & .980 & .961 & .992 & .018 & 55.678 & & \\
\hline & ERQ4 & .984 & .968 & - & & & & \\
\hline \multirow{2}{*}{$\begin{array}{c}\text { Job } \\
\text { satisfaction }\end{array}$} & JS1 & .865 & .749 & .910 & .075 & 12.179 & \multirow{2}{*}{0.674} & \multirow{2}{*}{0.805} \\
\hline & JS2 & .860 & .740 & - & & & & \\
\hline $\begin{array}{c}\text { Intention to } \\
\text { leave }\end{array}$ & IL & - & - & - & - & - & - & - \\
\hline
\end{tabular}

* Note: 1 . Average Variance Extracted $(\mathrm{AVE})=\left(\sum\right.$ standardized factor loadings $\left.{ }^{2}\right) /$

$\left[\left(\sum\right.\right.$ standardized factor loadings $\left.{ }^{2}\right)+\sum$ measurement errors $]$

2. Composite Construct Reliability $(\mathrm{CCR})=\left(\sum \text { standardized loadings }\right)^{2} /\left[\left(\sum \text { standardized loadings }\right)^{2}+\right.$ ( $\sum$ measurement errors)] 
Table 4. Correlation matrix

\begin{tabular}{|c|c|c|c|c|c|c|c|c|}
\hline \multirow[b]{2}{*}{ Construct } & \multicolumn{8}{|c|}{ Correlations among latent constructs (squared) } \\
\hline & CT & $\mathrm{CC}$ & CRQ & ET & EC & ERQ & JS & IL \\
\hline CT & 1.00 & & & & & & & \\
\hline CC & $\begin{array}{c}0.378 \\
(0.143)\end{array}$ & 1.00 & & & & & & \\
\hline CRQ & $\begin{array}{c}0.074 \\
(0.005)\end{array}$ & $\begin{array}{c}0.023 \\
(0.001)\end{array}$ & 1.00 & & & & & \\
\hline ET & $\begin{array}{c}0.322 \\
(0.104)\end{array}$ & $\begin{array}{c}0.244 \\
(0.060)\end{array}$ & $\begin{array}{c}0.099 \\
(0.010)\end{array}$ & 1.00 & & & & \\
\hline EC & $\begin{array}{c}0.351 \\
(0.123)\end{array}$ & $\begin{array}{c}0.415 \\
(0.172)\end{array}$ & $\begin{array}{c}0.142 \\
(0.020\end{array}$ & $\begin{array}{c}0.590 \\
(0.348)\end{array}$ & 1.00 & & & \\
\hline ERQ & $\begin{array}{c}0.044 \\
(0.002)\end{array}$ & $\begin{array}{c}-0.006 \\
(0.000)\end{array}$ & $\begin{array}{c}0.787 \\
(0.619)\end{array}$ & $\begin{array}{c}0.119 \\
(0.014\end{array}$ & $\begin{array}{c}0.150 \\
(0.023)\end{array}$ & 1.00 & & \\
\hline JS & $\begin{array}{c}0.373 \\
(0.139)\end{array}$ & $\begin{array}{c}0.333 \\
(0.111)\end{array}$ & $\begin{array}{c}0.088 \\
(0.008)\end{array}$ & $\begin{array}{c}0.625 \\
(0.391)\end{array}$ & $\begin{array}{c}0.545 \\
(0.297)\end{array}$ & $\begin{array}{c}0.111 \\
(0.012)\end{array}$ & 1.00 & \\
\hline IL & $\begin{array}{c}0.008 \\
(0.000) \\
\end{array}$ & $\begin{array}{c}0.075 \\
(0.006) \\
\end{array}$ & $\begin{array}{c}-0.624 \\
(0.389) \\
\end{array}$ & $\begin{array}{c}-0.072 \\
(0.005) \\
\end{array}$ & $\begin{array}{c}-0.075 \\
(0.006) \\
\end{array}$ & $\begin{array}{c}-0.617 \\
(0.381) \\
\end{array}$ & $\begin{array}{c}-0.044 \\
(0.002) \\
\end{array}$ & 1.00 \\
\hline Mean & 4.400 & 5.27 & 4.048 & 5.090 & 5.570 & 4.070 & 5.195 & 3.880 \\
\hline S.Dev & 1.035 & 1.147 & 1.490 & 1.153 & 1.063 & 1.738 & 1.275 & 1.650 \\
\hline
\end{tabular}

\subsection{Structural model analysis}

After assessing the goodness-of-fit, reliability, and validity of the measurement model, a structural equation model (SEM) was tested to assess whether the hypothesized conceptual model showed consistency with the collected data using the maximum likelihood (ML) method of estimation. The overall model fit showed adequate levels with the exception of the chi-square value, $\chi^{2}(199)=785.549(p=.000)$. Other indices were TLI=0.941, CFI $=0.949, \mathrm{NFI}=0.933$, GFI $=0.866$, AGFI $=0.830$, and RMSEA $=0.079$. Bentler and Chou (1987) suggest that models with more than 30 items and 5 constructs seldom have a very good fit with data. Given that the model proposed in this study includes 8 constructs, it can be considered to have modest goodness of fit.

Table 5 presents the standardized coefficients of all the constructs for the proposed structural model. The relationships between customer trust and customer commitment $\left(\gamma_{11}=.445\right.$, 6.696, $p<0.001)$ and between employee trust and employ commitment $\left(\gamma_{22}=.583,12.459, p<\right.$ 
0.001) were significant. However, while relationship quality with employees during internship had a positive impact on relationship quality with customers $\left(\beta_{34}=.665,23.494, p<0.001\right)$, both customer trust and commitment were not positively related to relationship quality with customers during internship. Employee trust did not show positive influence on relationship quality with employees, but the relationship between employee commitment and relationship quality with employees was significant $\left(\beta_{42}=.223,1.998, p<0.05\right)$. Relationship quality with customers during internship was negatively related to intention to leave $\left(\beta_{63}=-.415,-6.126, p<0.001\right)$, but no relationship was found between relationship quality with customers and job satisfaction.

Likewise, relationship quality with employees during internship was negatively related to intention to leave $\left(\beta_{64}=-.321,-5.641, p<0.001\right)$, but no relationship was discovered between relationship quality with employees and job satisfaction. Figure 1 presents the structural model with the overall standardized coefficients.

Table 5. Results of SEM analysis of overall student dataset $(N=471)$

\begin{tabular}{|c|c|c|c|c|c|}
\hline $\begin{array}{l}\text { Regression Path } \\
\text { Upscale }\end{array}$ & $\begin{array}{c}\text { Standard } \\
\text { Paths } \\
\text { Coefficient }\end{array}$ & Standard Error & $\begin{array}{l}\text { Critical Ratio } \\
\text { (t-value) }\end{array}$ & $p$-value & Decision \\
\hline $\mathrm{CT} \rightarrow \mathrm{CC}$ & .445 & .066 & 6.696 & $* * *$ & Accept \\
\hline $\mathrm{CT} \rightarrow \mathrm{CRQ}$ & .043 & .063 & .682 & .495 & Reject \\
\hline $\mathrm{CC} \rightarrow \mathrm{CRQ}$ & .025 & .051 & .491 & .623 & Reject \\
\hline $\mathrm{ET} \rightarrow \mathrm{EC}$ & .583 & .047 & 12.459 & $* * *$ & Accept \\
\hline $\mathrm{ET} \rightarrow \mathrm{ERQ}$ & .085 & .109 & .785 & .433 & Reject \\
\hline $\mathrm{EC} \rightarrow \mathrm{ERQ}$ & .223 & .112 & 1.998 & $.046^{*}$ & Accept \\
\hline $\mathrm{ERQ} \rightarrow \mathrm{CRQ}$ & .665 & .028 & 23.494 & $* * *$ & Accept \\
\hline $\mathrm{CRQ} \rightarrow \mathrm{JS}$ & .009 & .062 & .139 & .890 & Reject \\
\hline $\mathrm{CRQ} \rightarrow \mathrm{IL}$ & -.415 & .068 & -6.126 & $* * *$ & Accept \\
\hline ERQ $\rightarrow$ JS & .077 & .053 & 1.462 & .144 & Reject \\
\hline $\mathrm{ERQ} \rightarrow \mathrm{IL}$ & -.321 & .057 & -5.641 & $* * *$ & Accept \\
\hline \multicolumn{6}{|c|}{$\chi^{2}(199)=785.549(p=.000) ; \mathrm{TLI}=0.941 ; \mathrm{CFI}=0.949 ; \mathrm{RMSEA}=0.079 ; \mathrm{NFI}=0.933 ; \mathrm{GFI}=0.866 ; \mathrm{AGFI}=0.830$} \\
\hline
\end{tabular}

* Note: 1 . CT (customer trust), CC (customer commitment), CRQ (relationship quality with customers), ET (employee trust), EC (employee commitment), ERQ (relationship quality with employees), JS (job satisfaction), and IL (intention to leave)

2. *** $p<0.001$, ** $p<0.01, * p<0.05$ 
Figure 1. Relationship paths of overall student dataset $(N=471)$

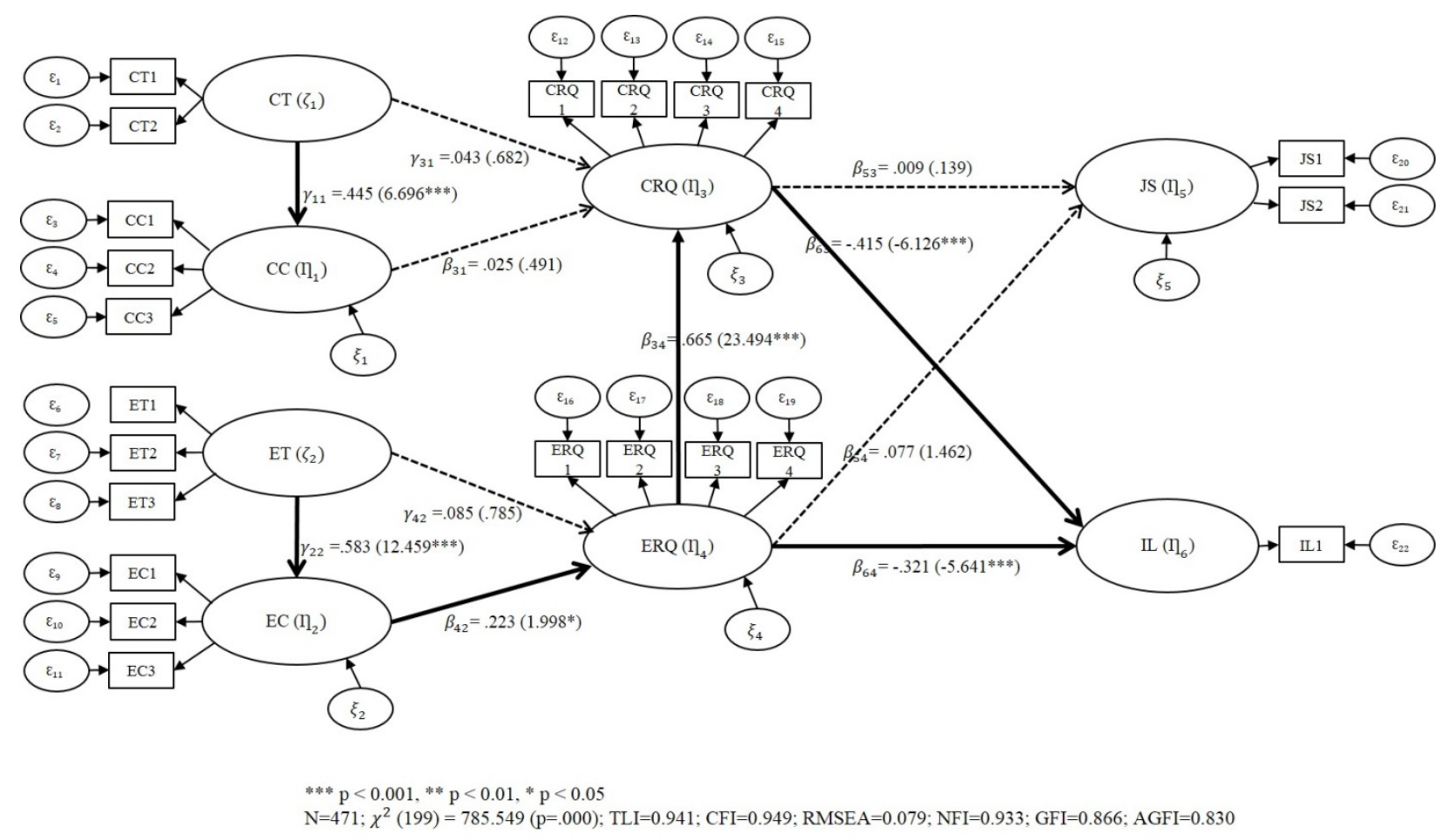

To compare the structural model between male and female participants, this study conducted a multi-group analysis procedure of SEM (Kim, Lee, \& Prideaux, 2014; Han et al., 2008). In the first stage, a chi-square difference test was conducted to evaluate measurement invariance, which is a prerequisite procedure of multi-group analysis (Mullen, 1995; Myers et al., 2005). The test's purpose is to compare the chi-square difference between CFA analysis of a nonrestricted model and that of the full metric invariance. If the chi-square difference is not significant, the two measurement models are invariant and support to compare the relationship paths between different groups (Cheung \& Rensvold, 2002; Kline, 1998).

In the measurement model of male and female datasets shown in Table 6, the chi-square (df) of the non-restricted model was 711.223 (364) and that of the full metric invariance of the CFA model was 726.132 (378). The difference between the two models was 14.909 (14) which is lower than $\chi_{.05}^{2}(14)=23.6848$. As a result, it was not significant, thus, the two models (Male vs. 
Female) were supported for comparison analysis of SEM analysis. In the next stage, a structural invariance test was conducted and the results are presented in Table 7.

Table 6. Results of measurement invariance test

\begin{tabular}{ccccccc}
\hline Model & $\chi^{2}(\mathrm{df})$ & RMSEA & CFI & NFI & Sig. & Support \\
\hline Non-restricted & $711.223(364)$ & .045 & .969 & .938 & & \\
\hline $\begin{array}{c}\text { Full metric } \\
\text { invariance model }\end{array}$ & $726.132(378)$ & .044 & .969 & .937 & $\begin{array}{c}p<.05 \\
\text { not significant }\end{array}$ & Support \\
\hline
\end{tabular}

* Note: Chi-square difference test $\Delta \chi^{2}(14)=14.909, \chi_{.05}^{2}(14)=23.68$

Table 7. Results of structural invariance test for gender groups

\begin{tabular}{ccccccc}
\hline Model & $\chi^{2}(\mathrm{df})$ & RMSEA & CFI & NFI & Sig. & Support \\
\hline $\begin{array}{c}\text { Full metric } \\
\text { invariance of } \\
\text { structural model }\end{array}$ & $1068.705(398)$ & .060 & .939 & .907 & & \\
\hline $\begin{array}{c}\text { Full path } \\
\text { invariance }\end{array}$ & $1086.443(414)$ & .059 & .939 & .906 & $\begin{array}{c}p<.01 \\
\text { not significant }\end{array}$ & Support \\
\hline
\end{tabular}

* Note: Chi-square difference test $\Delta \chi^{2}(16)=17.738, \chi_{.01}^{2}(16)=23.54$

Multi-group analysis revealed interesting gender differences. Relationship paths for male and female datasets are presented in Figure 2 and Figure 3. Critical ratios for differences between parameters revealed that the three paths (i.g., ET $\rightarrow \mathrm{ERQ}, \mathrm{CRQ} \rightarrow \mathrm{JS}$ and ERQ $\rightarrow \mathrm{JS}$ ) have significant differences between male and female datasets. Unlike the overall model, in the male dataset, no relationship was found between employee commitment and relationship quality with employees. Relationship quality with customers during internship had a positive impact on job satisfaction $(\beta=.378$ (4.096), $p<0.001)$ and a negative impact on intention to leave $(\beta=-.265(-$ 2.593), $\mathrm{P}<0.01$ ). Also, relationship quality with employees during internship had a positive impact on job satisfaction $(\beta=.332(4.029), p<0.001)$ and a negative impact on intention to leave $(\beta=-.360$ (-3.922), $\mathrm{P}<0.001)$. 
In the female dataset, both employee trust $(\beta=.238(2.105), \mathrm{p}<0.05)$ and employee commitment $(\beta=.344$ (2.833), $\mathrm{p}<0.01$ ) were positively related to relationship quality with employees, although both customer trust and customer commitment were still not significant factors for relationship quality with customers. Relationship quality with employee during internship had a positive impact on job satisfaction $(\beta=.408(6.102), p<0.001)$ and a negative impact on intention to leave $(\beta=-.242$ (-3.320), $\mathrm{P}<0.001)$. Interestingly, however, relationship quality with customer during internship is negatively related to both job satisfaction ( $\beta=-.238$ (2.98), $\mathrm{p}<0.01)$ and intention to leave $(\beta=-.482(-5.320), \mathrm{p}<0.001)$.

Figure 2. Relationship paths of male dataset $(N=219)$

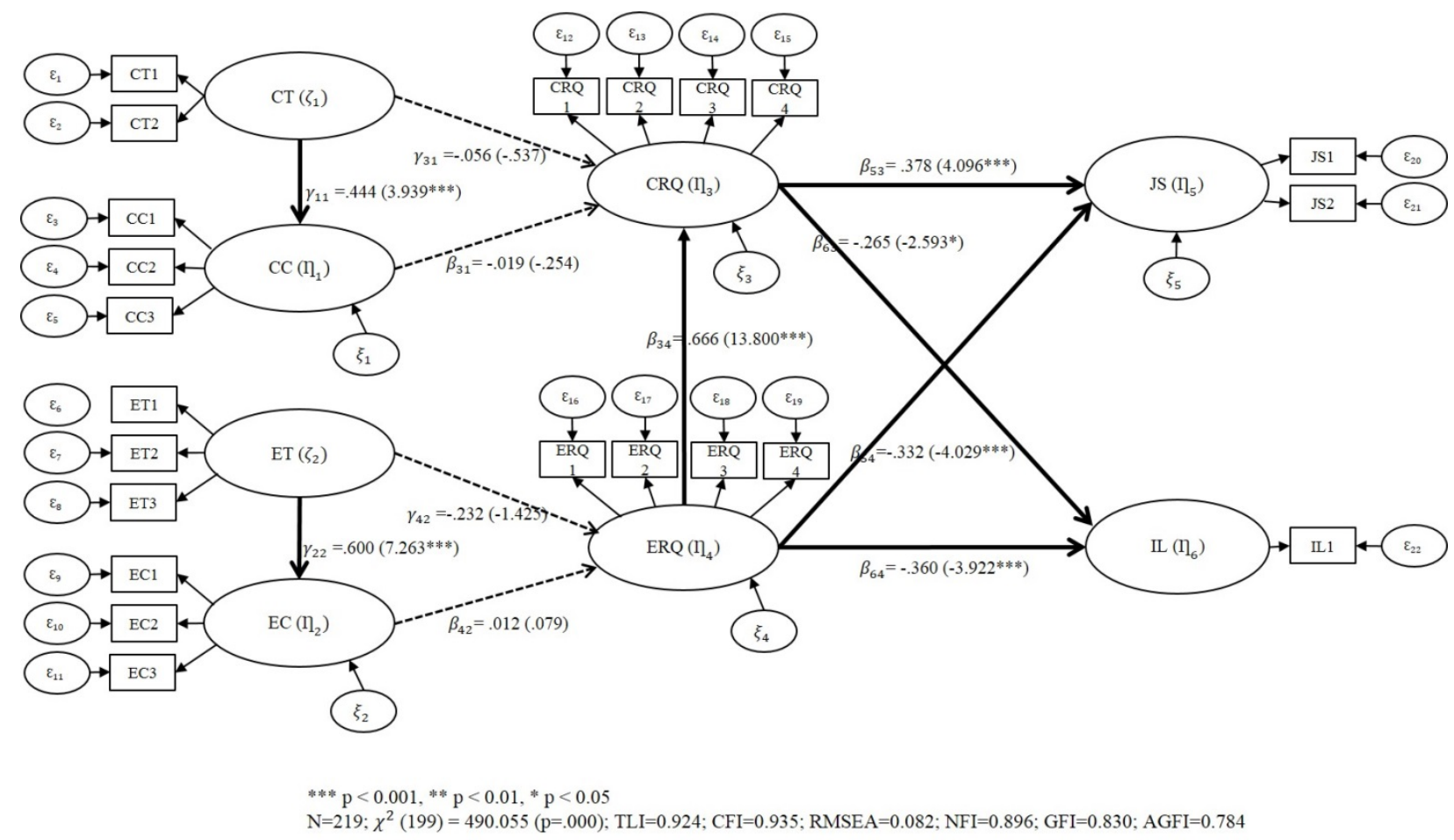


Figure 3. Relationship paths of female dataset $(N=252)$

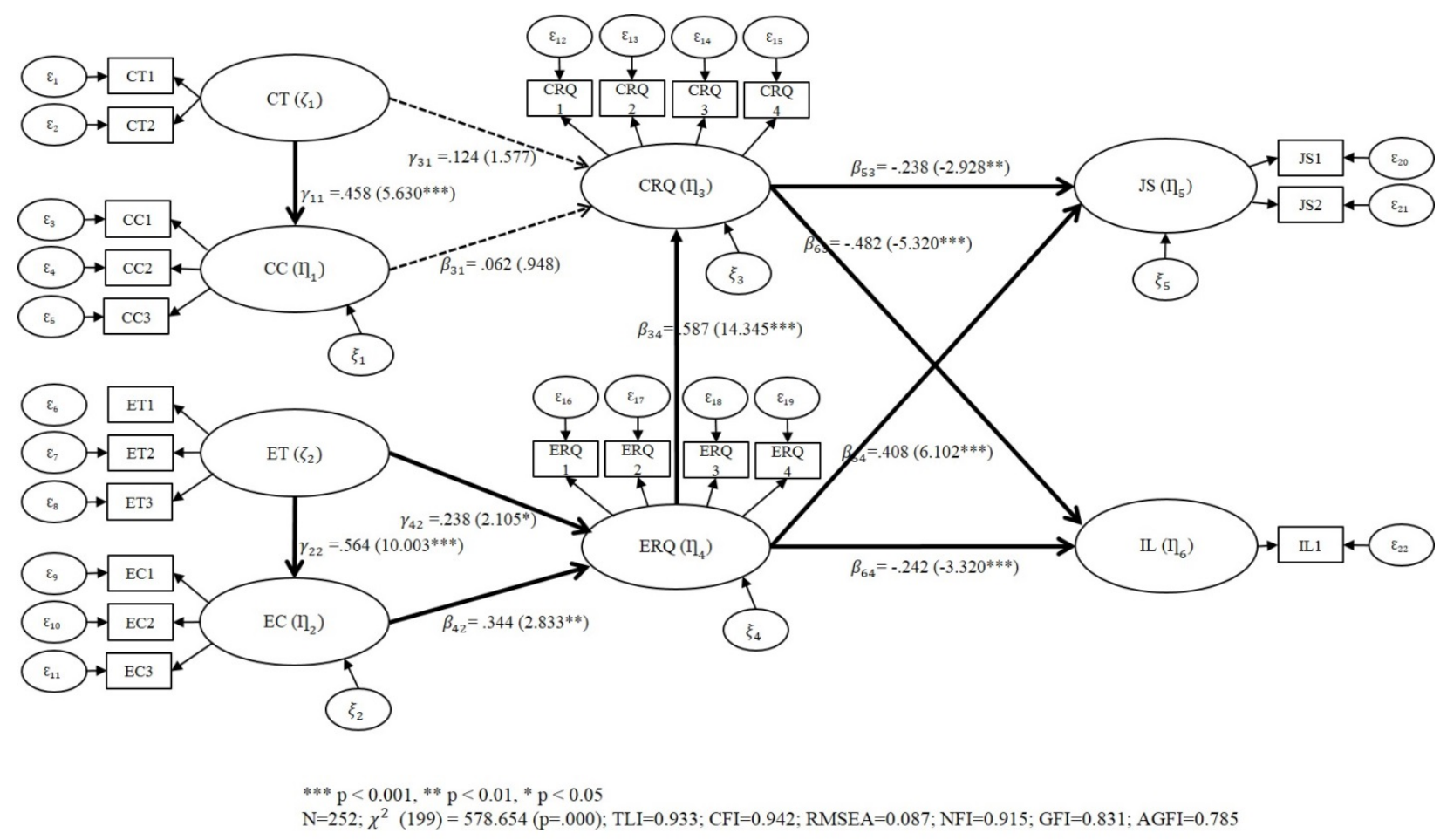

\section{Discussion}

Employee turnover is an ongoing challenge in the hospitality industry. The direct costs of recruiting new employees include the costs of recruitment agencies, interviewing and evaluating potential candidates and finding replacements while the recruitment process is in progress.

Because employee turnover is costly, it is important for hotels to develop a strategy to retain employees and keep turnover low. Abundant research has pointed to lower levels of organizational commitment and higher turnover rates among Millennial employees compared to previous generations in various industries. The Pew research center reported that the Millennial population is expected to peak in 2036 at 81.1 million individuals and that there will be a projected 79.2 million Millennials in the U.S. by 2050. For that reason, it has become critical for hotels to make their company attractive to Millennials and understand how to supervise them and help them develop their careers within their organization. In addition, as the number of female students in the tourism and hospitality programs and women employed in the hospitality industry increase, 
recognizing gender differences has emerged as a key issue for hotel operators. Therefore, this study attempted to better understand whether relationship quality is important for the Millennial generation as it pertains to their career intentions (i.e. whether or not to stay within the hospitality industry) and to ascertain whether or not there is any gender difference. Fostering good relationships among colleagues, for an instance, can help increase Millennials' job satisfaction and reduce employees' intention to leave the industry.

The generalizability of this research is limited by the convenience sampling and the fact that respondents were students from only one hospitality program. This study, however, highlights the substantial impact of relationship quality with colleagues during internship on Millennials' job satisfaction and their intention to leave the hospitality industry. In particular, both relationship quality with customer and colleagues during internship have negative impacts on intention to leave. Previous research mainly explored the differences between Millennials and the previous generation and little research has been conducted to explain the theoretical reason. Further research should identify which factors are associated with the quality of Millennials relationships with co-workers. Social exchange theory has been applied as a framework to predict employee behavior and attitude in organizational research (Settoon, Bennett, \& Liden, 1996). Blau (1964, p. 93), which has defined a 'social exchange relationship' as concerning obligations in which there are "favors that create diffuse future obligations, not precisely defined ones, and the nature of the return cannot be bargained about but must be left to the discretion of the one who makes it.” According to social exchange theory, an exchange starts with one party giving a benefit to another. If the recipient responds, and consequently a series of beneficial exchanges occurs, feelings of mutual obligation between the parties are created (Coyle-Shapiro \& Shore, 2007). Future studies may use social exchange theory as a theoretical framework and examine how Millennial employees perceive beneficial exchanges of maintaining good relationships with colleagues. 
In addition, multi-group analysis delivered valuable insights into gender differences. Both Trust and Commitment were significant antecedents of relationship quality with colleagues for the female data set, but no relationship was found for the male data set. Further research on antecedents of relationship quality between Millennial employees and customers are needed. Interestingly, the relationship between relationship quality with customers and job satisfaction is positive in the male group, whereas the relationship in the female group is negative. In contrast to this result, the relationship between relationship quality with colleagues and job satisfaction is negative in the male group, but the relationship in the female group is positive. Previous research found that gender does exert influence on the way in which individuals engage in relationships. For example, women tend to take greater responsibility for maintaining relationships than men (Thompson \& Walker, 1989). In addition, many studies found gender differences in emotional labor and emotional control in service procedures (O’Connor, Trinh, \& Shewchuk, 2000). Petrović et al. (2014) found gender differences among hotel employees in service orientation and that organizational support is more relevant to men because they believe structured labor and service procedures are more important than women. On the other hand, customer focus is more important to women because they wish to meet guests’ needs and try to have a good relationship with them (Petrović et al., 2014). Therefore, as female Millennials put strive to enhance customer relationships, they may feel more stress from their job leading to less job satisfaction and high turnover intention. However, additional research is needed to provide a theoretical explanation of this. Future research could explore the relationship between relationship quality and service orientations focusing on gender differences. In addition, future research may further investigate the generational differences in service orientation and career intention in the hospitality industry.

The hospitality industry and universities that offer related academic programs should work together to create an effective and high-quality internship program to retain top employees within 
the tourism and hospitality industry (Donina, 2015). This result suggests that industry practitioners should put their efforts into improving relationships among employees and customers in order to retain their employees. Management should promote healthy employee relations in the workplace so that all employees can perform to the best of their ability. Effective communication among employees and small social activities such as birthday parties may strengthen the bond among employees. Good communication is very important in the workforce. Hotel operators can provide opportunities for their managers to interact more with other employees to build stronger teamwork among them while allowing managers to help individual employees in improving their skills. Moreover, the positive relationship between relationship quality with colleagues and relationship quality with customers was found. In other words, when employees maintain good relationship quality with their colleagues, they can have good relationships with customers too. Since there are gender differences among Millennials in the relationship between relationship quality with customer and colleagues and career intention, hoteliers should have in mind that male and female Millennials respond differently depending on their perceived relationship quality with customers and colleagues and their career intention varies because of it. 


\section{References}

Adidam, P. T., Bingi, R. P., \& Sindhav, B. (2004). Building relationship between business school and students: An empirical investigation into student retention. Journal of College Teaching \& Learning, 1(11), 37-48.

Barron, P., \& Maxwell, G. (1993). Hospitality management students' views of the hospitality industry. International Journal of Contemporary Hospitality Management, 5(5), 5-8.

Becerra, M., \& Gupta, A. K. (1999). Trust within the organization: Integrating the trust literature with agency theory and transaction costs economics. Public Administration Quarterly, 23 (2), 177-204.

Blau, P. (1964). Exchange and Power in Social Life. New York: John Wiley \& Sons, Inc.

Brown, E. A., Thomas, N. J., \& Bosselman, R. H. (2015). Are they leaving or staying: A qualitative analysis of turnover issues for Generation Y hospitality employees with a hospitality education. International Journal of Hospitality Management, 46, 130-137.

Caruso, D. R., Mayer, J. D., \& Salovey, P. (2002). Relation of an ability measure of emotional intelligence to personality. Journal of Personality Assessment, 79, 306-320

Cave, P., \& Kilic, S. (2010). The role of women in tourism employment with special reference to Antalya, Turkey. Journal of Hospitality Management and Marketing, 19, 280-292.

Cairncross, G., \& Buultjens, J. (2007). Generation Y and work in the tourism and hospitality industry: Problem? What problem?, Centre for Enterprise Development and Research Occasional Paper, no. 9, Southern Cross University, Coffs Harbour, NSW.

Chang, S., Walsh, K., \& Tse, E. C. Y. (2014). Understanding students intentions to join the hospitality industry the role of emotional intelligence, service orientation, and industry satisfaction. Cornell Hospitality Quarterly, 56(4), 369-382.

Cole, N. D. (2004). Gender differences in perceived disciplinary fairness. Gender, Work and Organization, 11(3), 254-279.

Coyle-Shapiro, J., \& Shore, L. (2007). The employee-organization relationship: Where do we go from here? Human Resource Management Review, 17(2), 166-179.

Crosby, A. L., Evans K. R., \& Cowles D. (1990). Relationship Quality in Service Selling: An

Interpersonal Influence Perspective. Journal of Marketing, 54(3), 68-81.

Chuang, N., Goh, B.K., Stout, B.L., \& Dellmann-Jenkin, M. (2007). Hospitality undergraduate students' career choices and factors influencing commitment to the profession. Journal of Hospitality \& Tourism Education, 19(4), 28-37

Chuang, N-K., \& Dellmann-Jenkis, M. (2010). Career decision making and intention: A study of hospitality undergraduate students. Journal of Hospitality \& Tourism Research, 34, 512530.

Doniņa, A. (2015). The role of tourism and hospitality companies in ensuring an effective internship process. The Journal of Education Culture and Society, 2015(1), 281-290.

Eagly, A. H. (1987). Sex Differences in Social Behavior: A Social-Role Interpretation. Hillsdale, NJ.

Earle, H. A. (2003). Building a workplace of choice: Using the work environment to attract and retain top talent. Journal of Facilities Management, 2(3), 244-257.

Erickson, T. J. (2008). Plugged in: The Generation Y Guide to Thriving at Work. Harvard Business Press: Boston, MA.

Feldman, D. C. (2003). The antecedents and consequences of early career indecision among young adults. Human Resource Management Review, 13(3), 499-531. 
Ferris, G. R., Berkson, H. M., \& Harris, M. M. (2002). The recruitment interview process persuasion and organization promotion in competitive labor markets. Human Resource Management Review, 12(3), 359-375.

Fox, T. (2001). A sense of place. Caterer and Hotelkeeper, 189(4160), 30-31.

Freeland, B. (2000). Demands of training: Australian tourism and hospitality. Adelaide, Australia: National Center for Vocational Education Research.

Frazier, G. L., Gill, J., \& Kale, S. (1989). Dealer dependence levels and reciprocal actions in a channel of distribution in a developing country. Journal of Marketing, 53(1), 50-69.

Getz, D. (1994). Students' work experiences, perceptions and attitudes towards careers in hospitality and tourism: A longitudinal case study in Spey Valley, Scotland. International Journal of Hospitality Management, 13(1), 25-37.

García-Pozo, A., Campos-Soria, J. A., Sánchez-Ollero, J. L., \& Marchante-Lara, M. (2012). The regional wage gap in the Spanish hospitality sector based on a gender perspective. International Journal of Hospitality Management, 31, 266-275.

Glass, A. (2007). Understanding generational differences for competitive success. Industrial and Commercial Training, 38(2), 98-103.

Hair, J. F., Jr., Black, W. C., Babin, B. J., \& Anderson, R. E. (2010). Multivariate Data Analysis (7th edition). Upper Saddle River NJ: Pearson Prentice Hall.

Jarvelin, A., \& Lehtinen, U. (1996). Relationship quality in business-to-business service context, in Edvardsson, B.B., Johnston, S.W. and Scheuing, R. (Eds), QUIS 5 Advancing Service Quality: A Global Perspective, Warwick Printing Company Ltd, Toronto, pp. 243-254.

Jenkins, A. K. (2001). Making a career of it? Hospitality students' future perspectives: an AngloDutch study. International Journal of Contemporary Hospitality Management, 13(1), 1320.

Johns, N., \& McKechnie, M. (1995). Career demands and learning perceptions of hotel and catering graduates - ten years on. International Journal of Contemporary Hospitality Management, 7(5), 9-12.

Johnson, J. L. (1999). Strategic integration in industrial distribution channels: Managing the interfirm relationship as a strategic asset. Journal of the Academy of Marketing Science, 27(1), 4-18.

Kara, D., Uysal, M., \& Magnini, V.P. (2012). Gender differences on job satisfaction of the fivestar hotel employees: the case of the Turkish hotel industry, International Journal of Contemporary Hospitality Management, 24(7), 1047-1065.

Kelley-Paterson, D., \& George, C. (2001). Securing graduate commitment: an exploration of the comparative expectations of place students, graduate recruits and human resources managers within the hospitality, leisure and tourism industries. Hospitality Management, 20, 311-323.

Kim, B., Murrmann, S. K., \& Lee, G. (2009). Moderating effects of gender and organizational level between role stress and job satisfaction among hotel employees. International Journal of Hospitality Management, 28(4), 612-619.

King, B., McKercher, B., \& Waryszak, R. (2003). A comparative study of hospitality and tourism graduates in Australia and Hong Kong. International Journal of Tourism Research, 5, 409420.

Knight, J. (2000). Gen Y: How to train and retain it. Restaurant Hospitality, May, 88-90.

Ko, W. H. (2007). Training, satisfaction with internship programs, and confidence about future careers among hospitality students: A case study of universities in Taiwan. Journal of Teaching in Travel \& Tourism, 7(4), 1-15. 
Kwon, I. W., \& Suh, T. (2004). Factors affecting the level of trust and commitment in supply chain relationships. The Journal of Supply Chain Management, 40(2), 4-14.

Kupperschmidt, B. R. (2000). Multigeneration employees: Strategies for effective management. The Health Care Manager, 19, 65-76.

Kusluvan, S., \& Kusluvan, Z. (2000). Perceptions and attitudes of undergraduate tourism students towards working in the tourism industry in Turkey. Tourism Management, 21, 251-269.

Lam, T., \& Ching, L. (2007). An exploratory study of an internship program: The case of Hong Kong students. International Journal of Hospitality Management, 26, 336-351.

Lee, C., \& Farh, J. (1999). The effects of gender in organizational justice perception. Journal of organizational behavior, 20(1), 133-143.

Leslie, D., \& Richardson, A. (2000). Tourism and cooperative education in UK undergraduate courses: Are the benefits being realised? Tourism Management, 21, 489-498.

Martin, C. A. (2005). From high maintenance to high productivity: What managers need to know about Generation Y. Industrial and Commercial Training, 37(1), 39-44.

Mattila, A. (2001). Emotional bonding and restaurant loyalty. Cornell Hotel and Restaurant Administration Quarterly, 42(6), 73-79.

Meister, J. (2012, 5). Three reasons you need to adopt a Millennial mindset regardless of your age. Forbes. Retrieved from

http://www.forbes.com/sites/jeannemeister/2012/10/05/millennialmindse/

Moorman, C., Zaltman, G., \& Deshpandé R. (1992). Relationships between providers and users of market research: the Dynamics of trust within and between organizations. Journal of Marketing Research, 29(3), 314-328.

Morgan, R., \& Hunt, S. (1994). The commitment-trust theory of relationship marketing, Journal of Marketing, 58, July, 20-38.

Melnyk, V., van Osselaer, S. M. J., \& Bijmolt, T. H. (2009). Are women more loyal customers than men? Gender differences in loyalty to firms and individual service providers. Journal of Marketing, 73(4), 82-96.

Neuman, H. (1999). Internships. Career World, 27(6), 16.

Ndubisi, N. S. (2006). Effect of gender on customer loyalty: A relationship marketing approach. Marketing Intelligence \& Planning, 24(1), 48-61.

Noble, S. M., Griffith, D. A., \& Adjei, M. T. (2006). Drivers of local merchant loyalty: Understanding the influence of gender and shopping motives. Journal of Retailing, 82(3), 177-188.

Ng, C., \& Pine, R. (2003). Women and men in hotel management in Hong Kong: perceptions of gender and career development issues. International Journal of Hospitality Management, 22, 85-102.

Park, S., \& Henkin, A. B., \& Robert E. (2005). Teacher team commitment, teamwork and trust: Exploring association. Journal of Educational Administration, 43(5), 462-479.

Pinar, M., McCuddy, M. K., Birkan, I., \& Kozak, M. (2011). Gender diversity in the hospitality industry: an empirical study in Turkey. International Journal of Hospitality Management, 30, 73-81.

Petrović, M. D., Jovanović, T. Marković, J. J., Armenski, T., \& Marković, V. (2014). Why should gender differences in hospitality really matter? A study of personnel's service orientation and job satisfaction in hotels. Economic Research-Ekonomska Istraživanja, 27(1), 799-817.

Pruitt, D. G. (1981). Negotiation behavior. New York: Academic Press, Inc.

Raybould, M., \& Wilkins, H. (2005). Over-qualified and under-experienced: Turning graduates 
into hospitality managers. International Journal of Contemporary Hospitality Management, 17(3), 203-216.

Reevy, G. M., \& Maslach, C. (2001). Use of social support: Gender and personality differences. Sex Roles, 44(7-8), 437-459.

Richardson, S. (2008). Undergraduate tourism and hospitality students attitudes toward a career in the industry: A preliminary investigation. Journal of Teaching in Travel \& Tourism, 8(1), 23-46.

Richardson, S. (2010). Generation Y's perceptions and attitudes towards a career in tourism and hospitality. Journal of Human Resources in Hospitality \& Tourism, 9, 179-199.

Samuel, M. O., \& Chipunza, C. (2009). Employee retention and turnover: Using motivational variables as a panacea. African journal of Business Management, 3(8), 410-415.

Sánchez-Franco, M. J., Ramos, A. F. V., \& Velicia, F. A. M. (2009). The moderating effect of gender on relationship quality and loyalty toward Internet service providers. Information \& Management, 46(3), 196-202.

Santero-Sanchez, R., Segovia-Pérez, M., Castro-Nuñez, B., Figueroa-Domecq, C., \& TalónBallestero, P. (2015). Gender differences in the hospitality industry: A Job quality index. International Journal of Hospitality Management, 51, 234-246.

Settoon, R., Bennett, N., \& Liden, R. (1996). Social exchange in organizations: Perceived organizational support, leader-member exchange, and employee reciprocity. Journal of Applied Psychology, 81(3), 219-227.

Seymore II, D., \& Higham, M. T. (1996). The access guide to international affairs internships. Washington, DC: Access.

Seyitog lu, F., \& Yirik, S. (2015). Internship satisfaction of students of hospitality and impact of internship on the professional development and industrial perception. Asia Pacific Journal of Tourism Research, 20(1), 1414-1429.

Sui, J.J., \& Baloglu, S. (2003). The role of emotional commitment in relationship marketing: an empirical investigation of loyalty models for casinos. Journal of Hospitality \& Tourism Research, 27, 470-489.

Siu, G., Cheung, C., \& Law, R. (2012). Developing a conceptual framework for measuring future career intention of hotel interns. Journal of Teaching in Travel and Tourism, 12(2), 188215.

Solnet, D., \& Hood, A. (2008). Generation Y as hospitality employees: Framing a research agenda. Journal of Hospitality \& Tourism Management, 15(4), 59-68.

Tse, T. S. M. (2010). What do hospitality students find important about internships? Journal of Teaching in Travel and Tourism, 10(3), 251-264.

Walter, A., Muller T. A., Helfert G., \& Ritter T. (2003). Functions of industrial supplier relationships and their impact on relationship quality. Industrial Marketing Management, 32, 159-169.

Westerman, J. W., \& Yamamura, J. H. (2006). Generational preferences for work environment fit: Effects on employee outcomes. Career Development International, 22(2), 150-161.

Witt, L. A., \& Nye, L. G. (1992). Gender and the relationship between perceived fairness of pay or promotion and job satisfaction. Journal of Applied Psychology, 77, 910-917.

Whitelaw, P., \& Gillet, S. (2003). When the girls take over in hospitality and tourism. Tourism Recreation Research, 28(2), 41-50.

Wong, A., \& Sohal, A. (2002). An examination of the relationship between trust, commitment and relationship quality. International Journal of Retail \& Distribution Management, 30(1), 34-50. 